\title{
Echtscheiding, conflict en mentale gezondheid: hoe conflict met de ex- en nieuwe partner gerelateerd is aan welzijn na scheiding.
}

\author{
Sara Symoens ${ }^{1}$, Piet Bracke ${ }^{1}$ \\ 1 Universiteit Gent
}

\begin{abstract}
Veranderingen in sociale relaties kunnen een substantiële invloed hebben op het welbevinden van ex-partners na echtscheiding. In dit onderzoek wordt conflict in intieme relaties met zowel de nieuwe partner als de ex-partner bestudeerd, en de relatie tussen conflict en een waaier van zowel positieve als negatieve indicatoren van mentale gezondheid. De data van het project 'Scheiding in Vlaanderen' worden gebruikt. Analyses worden uitgevoerd op een subsample van 908 gescheiden mannen en vrouwen. In vergelijking met het voorbije huwelijk, wordt in huidige ex-partnerrelaties weinig conflict gerapporteerd. Is er toch conflict, dan gaat dit voor zowel mannen als vrouwen gepaard met een lager welzijn, maar vooral voor vrouwen. Hetzelfde geldt voor conflict met de nieuwe partner. Meest opvallend is dat partnerrelaties van centraal belang blijven voor de identiteit van mannen en vrouwen. Zij in een nieuwe partnerrelatie zijn gemiddeld immers meer tevreden en minder ongelukkig dan alleenstaanden, zelfs indien veel conflict gerapporteerd wordt. Tenslotte blijken gescheiden vrouwen, maar niet mannen, wiens voorbije huwelijk veel conflict kende doorgaans meer tevreden met hun leven te zijn.
\end{abstract}

\section{ECHTSCHEIDING, CONFLICT EN MENTALE GEZONDHEID IN CONTEXT ${ }^{1}$}

Sinds de jaren '60 wordt Europa gekenmerkt door een toename in het aantal echtscheidingen en België is één van de koplopers (eurofound.europa.eu). In 2005 werden er in ons land 71 echtscheidingen per 100 huwelijken voltrokken. In totale cijfers zijn dat ongeveer

1 Met dank aan Prof. Koen Matthijs (KU Leuven, Centrum voor Sociologisch Onderzoek, Family and Population Studies) en
60.000 mannen en vrouwen die per jaar een scheiding doormaken. Deze cijfers tonen aan dat steeds meer mensen geconfronteerd worden met een echtscheiding en alles wat dit met zich meebrengt. Verscheidene onderzoekers hebben zich dan ook reeds toegelegd op het bestuderen van haar gevolgen voor een brede waaier van levensdomeinen (Amato, 2000; Lansford, 2009). Studies omtrent mentale gezondheid en welzijn komen alle tot de

Mevr. Diana Evers (familiaal bemiddelaar, lid van de stuurgroep Bemiddeling vzw en mede oprichtster van De Scheidingsschool), voor hun bijdrage aan deze paper. 
bevinding dat uit de echt gescheiden personen het doorgaans minder goed stellen dan gehuwden en samenwonenden: ze rapporteren meer klachten van depressiviteit en hogere niveaus van stress en angst (Amato, 2000; Bracke, 1998; Shapiro, 1996; Simon \& Marcussen, 1999).

Wat mentale gezondheid betreft, voert Vlaanderen een preventief gezondheidsbeleid om gezondheidswinst op bevolkingsniveau te realiseren en zo de levenskwaliteit te verhogen. Een specifieke gezondheidsdoelstelling beoogt het bewerkstelligen van een daling van het aantal depressies en zelfdodingen (www.zorgen-gezondheid.be). Omdat gescheiden personen extra gevoelig zijn voor mentale problemen, en die groep toeneemt, is meer diepgaand onderzoek nodig naar de samenhang tussen relatieontbinding en mentale gezondheid. Dat is ook belangrijk voor het beleid en voor professionele hulpverleners.

Doorgaans gaat een echtscheiding gepaard met grote veranderingen in het leven van beide ex- partners. Beide moeten hun leven reorganiseren en hun identiteit herformuleren, wat extra stress met zich meebrengt. Vaak vernoemde stressoren zijn een verhoogde financiele last, verhuizen, en alleen instaan voor de zorg voor de kinderen of verminderd contact met de kinderen. Ook veranderingen in sociale netwerken kunnen een substantiële impact hebben op het welbevinden van gescheiden mannen en vrouwen. Verschillende onderzoekers focussen dan ook op sociale relaties, conflict en steun. Zij beklemtonen het belang van goede relaties met familie en vrienden, en het belang van een nieuwe partner (Horwitz, McLaughlin \& White, 1997; Terhell, Groenou \& Van Tilburg, 2007). In welke mate ook de relatie met de ex-partner na de scheiding een blijvende invloed op het welbevinden uitoefent, is evenwel nog onderbelicht. Toch is het belangrijk ook factoren op te nemen die deze ex-partnerrelatie typeren: vandaag worden ex-partners door een toename in het aantal co-ouderschapregelingen immers meer en meer gedwongen contact te houden met elkaar. Relatiekenmerken van voor de scheiding zijn evenzeer belangrijk: het ontbinden van een huwelijk gekenmerkt door conflict of chronische spanning, kan immers resulteren in een verbeterd

\section{Over het onderzoek Scheiding in Vlaanderen (SIV)}

SiV-data zijn afkomstig van het onderzoek "Scheiding in Vlaanderen". In dit onderzoek werd via een interview informatie verzameld bij beide partners van eerste huwelijken die afgesloten zijn tussen 1971 en 2008 en intussen al dan niet ontbonden zijn. Ook een kind, een ouder en een eventuele nieuwe partner van deze personen werden indien mogelijk bevraagd. Zij kregen een schriftelijke vragenlijst of websurvey aangeboden. De gegevens zijn verzameld in de periode van september 2009 tot december 2010.
12110 van alle 26376 gecontacteerde personen konden bevraagd worden wat een totale respons van $46 \%$ oplevert voor deze multi-actorstudie over huwelijk en echtscheiding. Gedetailleerde informatie over dit onderzoek en deze dataverzameling vindt $u$ op www.scheidinginvlaanderen.be en in het boek: Mortelmans Dimitri, Pasteels Inge, Bracke Piet, Matthijs Koen, Van Bavel Jan, Van Peer Christine (2011) Scheiding in Vlaanderen. ISBN 978-90-334-85862 - Leuven: Acco, 355 p. 
welzijn eerder dan in extra stress (Amato \& Hohmann-Marriott, 2007; Booth \& Amato, 1991; DeGarmo \& Kitson, 1996, Ross, 1999; Wheaton, 1990).

Hoewel het positief effect van gehuwd zijn en van de huwelijkskwaliteit op het welzijn van mannen en vrouwen reeds vaak aangetoond is, is over de impact van de voorbije huwelijkskwaliteit, en vooral over de kwaliteit van post echtscheidingsrelaties tussen ex-partners nog weinig geweten (Masheter, 1997). Deze lacune is deels te wijten aan een tekort aan degelijke data. Meestal ontbreekt belangrijke informatie, zoals de tijd verlopen sinds de scheiding of kenmerken van het voorbije huwelijk en de huidige relatie met de ex-partner. Meer inzicht verwerven in deze relaties is evenwel belangrijk, ook voor bemiddelaars en therapeuten die dikwijls met de realiteit en gevolgen van conflictueuze relaties te maken krijgen in hun praktijk (Evers, 2011). De laatste jaren wordt echtscheidingsbemiddeling door de Belgische wetgever immers naar voren geschoven als 'eerste lijn' voor het uitwerken van een echtscheidingsovereenkomst, teneinde ondermeer het aantal vechtscheidingen, en zo ook de emotionele impact van echtscheiding voor de betrokken partijen te minimaliseren (justitie.belgium.be). In lijn met de toenemende aandacht voor relatie- en echtscheidingsbemiddeling enerzijds, en mentale gezondheid anderzijds, wordt in deze bijdrage onderzocht hoe conflict in intieme relaties samenhangt met welzijn na scheiding.

2 Om een meer objectieve maat voor conflict tussen ex-partners te bekomen (zowel voor huidig conflict, als voor conflict tijdens het voorbije huwelijk), werd een samengestelde maat gecreeerd die het gemiddelde weergeeft van de scores van beide ex-partners. Deze maat is meer

\subsection{DATA}

De data van het onderzoek "Scheiding in Vlaanderen" werden gebruikt. 6470 gehuwde en ooit gescheiden personen tussen 21 en 83 jaar oud werden bevraagd in het kader van deze studie. Deze dataset is uniek aangezien het een steekproef is van huwelijkscohorten in Vlaanderen (gehuwd tussen 1971 en 2008), waarbij beide partners of momenteel ex-partners onafhankelijk van elkaar gecontacteerd zijn. We beperken ons voor dit onderzoek tot respondenten tussen 25 en 60 jaar die minimum 1 jaar en maximaal 10 jaar geleden gescheiden zijn en wiens ex-partner ook deelnam aan de studie ${ }^{2}$. Deze uiteindelijke steekproef bevat 908 respondenten (454 vrouwen en 454 mannen) ${ }^{3}$. Van deze respondenten leeft $46 \%$ van de gescheiden vrouwen en $55 \%$ van de gescheiden mannen samen met een nieuwe partner.

\subsection{ONDERZOEK}

Eerst worden een aantal theoretische inzichten en algemene cijfers inzake welzijn, relaties en conflict gepresenteerd. Vervolgens wordt de relatie tussen conflict (eerder huwelijksconflict, huidig conflict met de ex-partner, en conflict in de nieuwe partnerrelatie) en mentale gezondheid bekeken voor vier indicatoren van mentale gezondheid. Zowel negatief welbevinden (depressieve gevoelens (CESD, 8)) als positief welbevinden (zelfwaardering (Rosenberg, 1965), omgevingsbeheersing (Pearlin et al., 1981) en levenstevredenheid (Cantrill, 1965)) worden onderzocht. Zelfwaardering verwijst naar het al dan niet hebben van positieve gevoelens over zichzelf, of naar de mate waarin mensen zichzelf hoog of laag inschatten (Seff et

stabiel aangezien inschattingen van conflict, en zeker retrospectieve inschattingen, onderhevig kunnen zijn aan vertekening.

3 Voor meer informatie omtrent de selectie van de respondenten, zie bijlage 1 . 
al, 1992, p. 574). In lijn daarmee verwijst omgevingsbeheersing naar de mate van persoonlijke controle die men ervaart en macht (mastery) (Skaff, Pearlin \& Mullan, 1996, p. 247), of het geloof dat gebeurtenissen in het leven het resultaat zijn van het eigen handelen (Mirowsky and Ross 1989; Ross \& Mirowsky, 2002). Zelfwaardering en omgevingsbeheersing zijn belangrijke determinanten van effectief en efficiënt handelen en van zelfevaluatie in het dagelijks leven. Levenstevredenheid is een meer algemene positieve indicator van welzijn. De opname van negatieve en positieve indicatoren maakt een beter inzicht in mentaal welbevinden mogelijk aangezien mentale gezondheid meer is dan de afwezigheid van mentale problemen (Bradburn, 1969; Payton, 2009). Bovendien maakt de opname van indicatoren van positief functioneren het ook mogelijk af te wijken van het dominant discours waarin echtscheiding gezien wordt als een negatieve gebeurtenis die mensen passief ondergaan (Thoits, 1994), ten voordele van een meer actief discours dat mogelijkheden eerder dan risico's belicht. De focus van deze studie ligt dan ook op condities die 'kneedbaar' zijn, met name relaties.

Analyses worden gedaan in PASW 18.0 gebruik makende van MANOVA regressiemodellen. Deze schatten of er significante verschillen zijn voor verscheidene afhankelijke variabelen, tezelfdertijd controlerend voor de correlatie tussen deze afhankelijke variabelen. Voor alle dimensies van mentale gezondheid wordt een model samengesteld waarin tevens gecontroleerd wordt voor leeftijd, tijd sinds echtscheiding, het al dan niet hebben van gedeelde minderjarige kinderen met de ex-partner, hoogst behaalde opleidingsniveau, werkstatus en financiële situatie (relatief equivalent huishoudinkomen). Voor meer informatie over de constructie van alle variabelen, zie bijlage 2 .

\section{WELZIJN, RELATIES EN CONFLICT: INZICHTEN EN CIJFERS}

\subsection{EEN NIEUWE PARTNER}

Mensen die samenwonen met een partner rapporteren gewoonlijk een betere mentale gezondheid dan alleenstaanden en gescheiden en verweduwde personen zonder nieuwe partner. Eerdere studies tonen zelfs aan dat het vinden van een nieuwe partner wellicht één van de beste strategieën is om over de negatieve gevolgen van een echtscheiding heen te raken (Fokkema, 2001). De Vlaamse data (SiV, 200910) lijken dit te bevestigen: het gemiddeld welzijn van gescheiden mannen en vrouwen die samenleven met een nieuwe partner ligt quasi op hetzelfde niveau als dat van zij die nog steeds gehuwd zijn.

\section{Figuur 1: Gevoelens van depressiviteit $(\min =0, \max =10)$ naar partnerstatus}

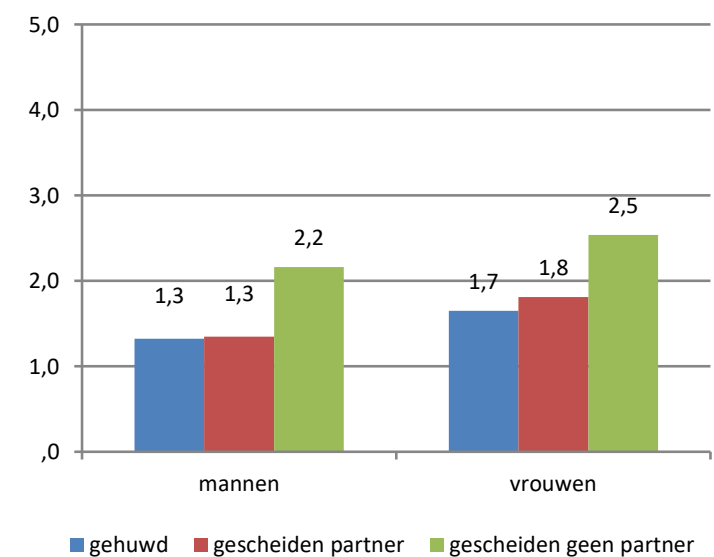

Figuur 2: Gevoelens van levenstevredenheid $(\min =0, \max =10)$ naar partnerstatus

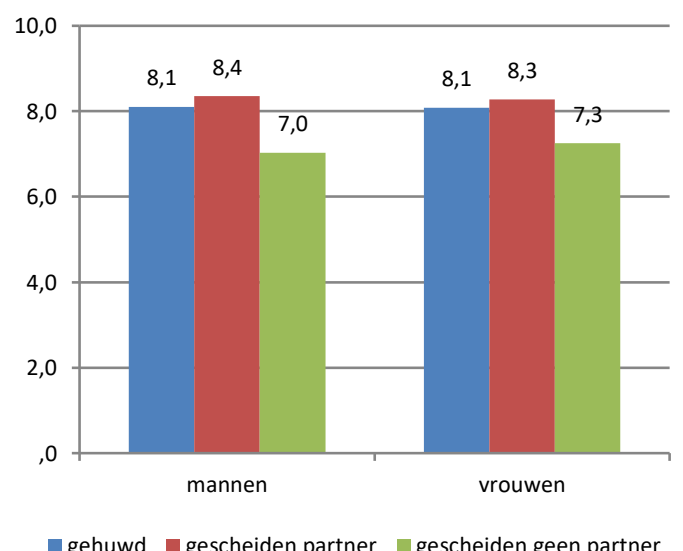


Zij die niet samenwonen met een partner zijn duidelijk minder goed af. Figuur 1 en Figuur 2 tonen dit aan voor gevoelens van depressiviteit, respectievelijk levenstevredenheid, voor de gehele dataset van het project Scheiding in Vlaanderen (schaal 0-10).

Mensen zijn van nature sociaal ingesteld, wat zich uit in een aanhoudend zoeken naar samenhorigheid en bevestiging. De mate waarin relaties een positieve impact uitoefenen op het welbevinden hangt dan ook af van de kwaliteit van deze relaties en de mate van conflict. Mannen ervaren doorgaans iets meer conflict dan vrouwen binnen hun nieuwe relatie (Tabel 1). De belangrijkste bron van conflict met de nieuwe partner is onenigheid over de opvoeding van de kinderen, gevolgd door onenigheid over de verdeling van huishoudelijke taken, het uiten van gevoelens, en de relatie met ouders en/of schoonouders (Figuur 3).

\subsection{DE HUIDIGE RELATIE MET DE EX-PARTNER}

Hoewel de impact van sociale relaties en sociale steun reeds vaak onderzocht is, blijft de expartner quasi steeds buiten beschouwing. Het is evenwel aannemelijk dat ook de kwaliteit van de huidige relatie met de ex-partner een invloed uitoefent op het welbevinden aangezien deze persoon gedurende lange tijd als spiegel voor het zelfbeeld fungeerde. We verwachten dan ook dat positieve relaties tussen ex-partners het algemeen welzijn nog steeds ten goede komen. Een studie van Masheter et al. (1997) toont aan dat naast conflict met de expartner ook een hoge mate van blijvende betrokkenheid gerelateerd is aan een lager welbevinden. Geen contact meer hebben, is bijgevolg mogelijks beter, aangezien het de afsluiting van een hoofdstuk in het leven (closure), en het maken van een nieuwe start vergemakkelijkt. Althans in de jaren zeventig was de dominante idee dat een voortdurende betrokkenheid tussen ex-partners pathologisch en emotioneel uitputtend is, en dat dit het vormen van nieuwe relaties bemoeilijkt (Ahrons, 2007). Vandaag reflecteren wetsveranderingen in Vlaanderen evenwel een andere realiteit: gezagsco-ouderschap is sinds 1995, en verblijfsco-ouderschap sinds 2006, de voorkeurdragende regeling voor minderjarige kinderen bij echtscheiding (Martens, 2007). Hierdoor is het breken van contact met de ex-partner voor velen makkelijk, noch gewenst. In onze steekproef heeft ongeveer $62 \%$ van de ex-koppels gezamenlijke minderjarige kinderen, en $40 \%$ gezamenlijke meerderjarige kinderen (cijfers niet weergegeven). Volgens Diana Evers (2011) zullen we dan ook anders moeten leren omgaan met het verloop, het verlies en het herbeginnen van relaties. "Onze kinderen zullen ons uiteindelijk dwingen anders met scheiding en verlies om te gaan dan we nu doen" (Evers, 2011).

Ongeveer $80 \%$ van de gescheiden koppels in onze steekproef heeft nog contact met elkaar (Tabel 1). Tabel 2 geeft weer hoeveel procent van de gescheiden koppels in onze steekproef nog contact heeft, naargelang er kinderen zijn of niet. 'Contact hebben' werd ruim gedefinieerd als het nog zien van, of het nog hebben van contact met de ex-partner via telefoon, post of internet. Resultaten bevestigen dat expartners met gemeenschappelijke minderjarige kinderen vaker nog contact houden, zeker in geval van co-ouderschap (96\%) (Tabel 2). 
Tabel 1. Beschrijving van de respondenten die max. 10 jaar geleden uit de echt scheidden, tussen 25 en 60 jaar zijn en wiens ex-partner ook deelnam aan de survey

\begin{tabular}{lcc}
\hline & \multicolumn{1}{c}{ Vrouwen } & Mannen \\
& $\mathrm{N}=454$ & $\mathrm{~N}=454$ \\
\cline { 2 - 3 } & Gemiddelde (SD) / \% & Gemiddelde (SD) / \% \\
\hline Nieuwe partner in huishouden? & $46,0 \%$ & $55,3 \%$ \\
Conflict met nieuwe partner (0-30) & $1,17(2,17)$ & $1,38(2,28)$ \\
Contact met ex-partner & $80,4 \%$ & $79,5 \%$ \\
Conflict met ex-partner nu (0-30) & $1,18(2,30)$ & $1,17(2,20)$ \\
$\quad$ >objectieve maat (combi van beide ex-partners) & $1,18(1,82)$ & $1,18(1,82)$ \\
Conflict voorbije huwelijk (0-30) & $9,57(6,37)$ & $7,95(5,45)$ \\
\multicolumn{1}{c}{ >objectieve maat (combi van beide ex-partners) } & $8,75(4,67)$ & $8,75(4,67)$ \\
Minderjarige kinderen met ex-partner & $62,8 \%$ & $60,6 \%$ \\
\hline
\end{tabular}

Figuur 3. Thema's van conflict met de nieuwe partner (percentage respondenten die soms, vaak of altijd aangaven) (SiV, 2009-10; $N_{\text {mannen }}=235 ; N_{\text {vrouwen }}=190$ )

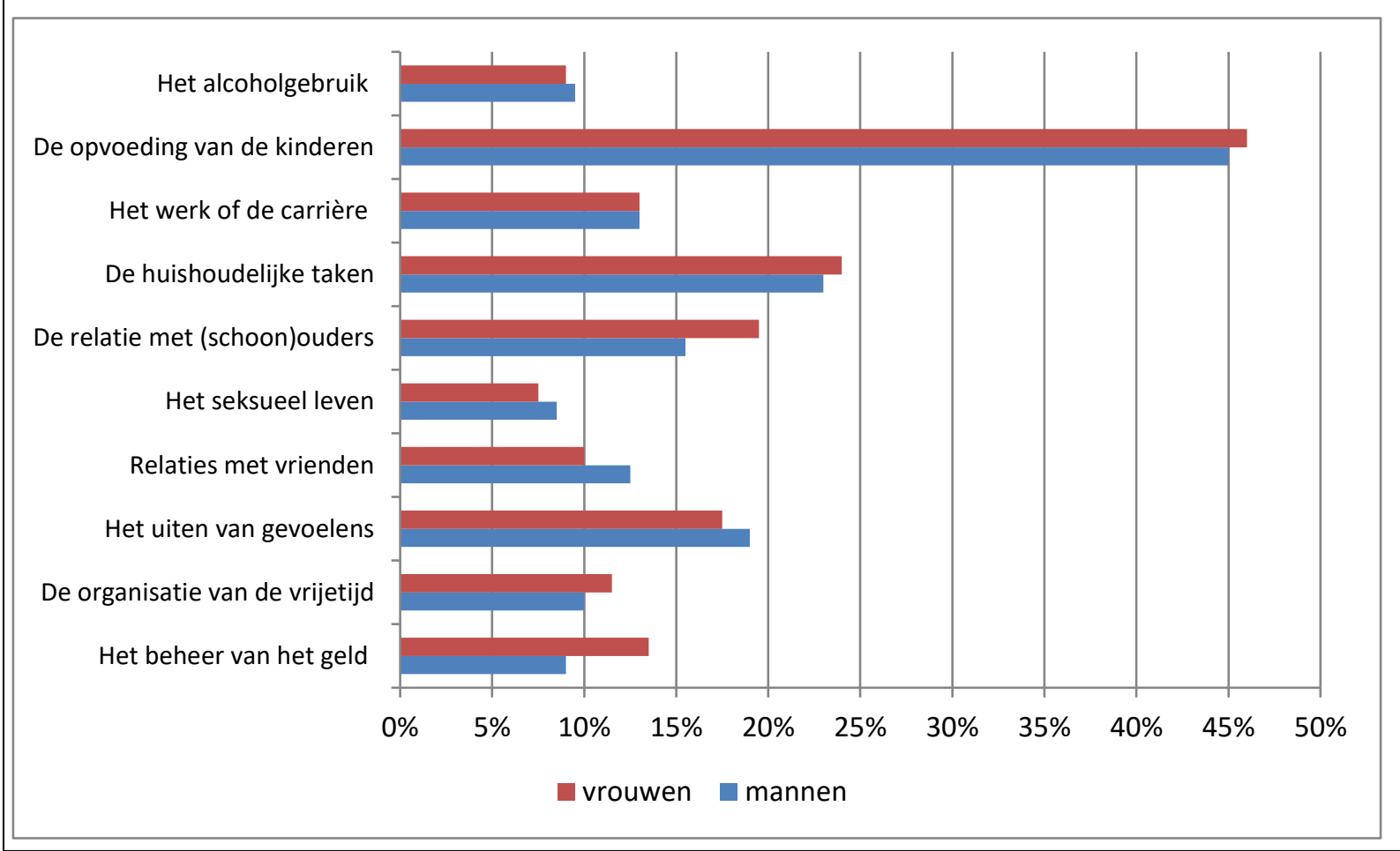


Figuur 4. Reden geen contact meer met ex-partner (SiV, 2009-10; $\left.N_{\text {mannen }}=93 ; N_{\text {urouwen }}=89\right)$

1. Wij wonen te ver van elkaar

2. $\mathrm{Hij} / \mathrm{Zij}$ wil geen contact meer

3. Ik wil geen contact meer

4. We hebben ruzie

5. Het contact is verwaterd

6. Contactverbod opgelegd door rechter

7. Andere
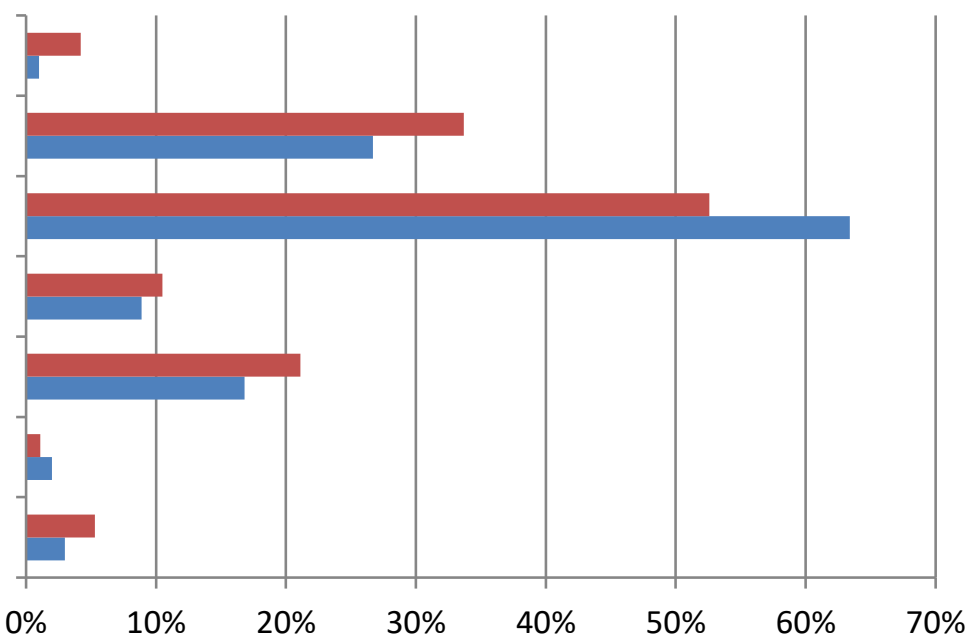

vrouwen mannen

Toch is er ook bij $67 \%$ van de ex-koppels zonder gemeenschappelijke minderjarige kinderen nog contact. Indien alle contact verbroken werd, is dat vooral omdat men de banden met deze ex-partner wenst door te snijden.Dat is iets vaker de wens van mannen (Figuur 4).

Tabel 2. Wie heeft nog contact met zijn/haar ex-partner?

\begin{tabular}{lc}
\hline \multicolumn{2}{l}{ Percentage dat nog contact heeft met ex-partner } \\
\hline geen minderjarige kinderen & $67 \%$ \\
minderjarige kinderen bij 1 ouder (moeder) & $77 \%$ \\
minderjarige kinderen in gedeeld verblijf ${ }^{4}$ & $96 \%$
\end{tabular}

Doorgaans wordt weinig conflict tussen expartners na echtscheiding gerapporteerd en liggen de gemiddelde scores van mannen en

4 Gedeeld verblijf wordt ruim gedefinieerd en gebruikt voor die kinderen wiens ouders aangeven dat het kind inwonend is bij hen, maar deels ook vrouwen quasi gelijk $(R=0,310, p<0.01)$ (Tabel 1). Indien er toch conflict gerapporteerd wordt met de ex-partner uit zich dit vaakst in verwijten maken of niet meer praten met elkaar (Figuur 5).

\subsection{HET VOORBIJE HUWELIJK}

Volgens sommige psychologen laten langdurige, weinig kwalitatieve en conflictueuze relaties blijvende sporen na op iemands identiteit, zelfwaardering en capaciteit om met problemen om te gaan (Umberson, e.a, 2006). Naast de huidige relatie met de ex-partner, kan dus ook de mate waarin het voorbije huwelijk gekenmerkt werd door stress en conflict een blijvende impact op het welbevinden hebben. Stress en conflict tasten immers de psychische veerkracht aan, wat voelbaar is vaak tot lang nadat de relatie beëindigd werd (problem

verblijft in het huishouden van de ex-echtgeno(o)t(e). 
Figuur 6. Inschatting conflict de laatste 12 maanden van het voorbije huwelijk (percentage respondenten dat aangaf dat dit minimaal verschillende keren per maand tot maximaal dagelijks gebeurde) (SiV, 2009-10; $N_{\text {mannen }}=454 ; N_{\text {urouwen }}=454$ )

Figuur 5. Inschatting conflict met ex-partner de voorbije 12 maanden (percentage respondenten dat aangaf dat dit minimaal verschillende keren per maand tot maxiamaal dagelijks gebeurde) (SiV, 2009-10; $\mathbf{N}_{\text {mannen }}=454 ; N_{\text {vrouwen }}=454$ )

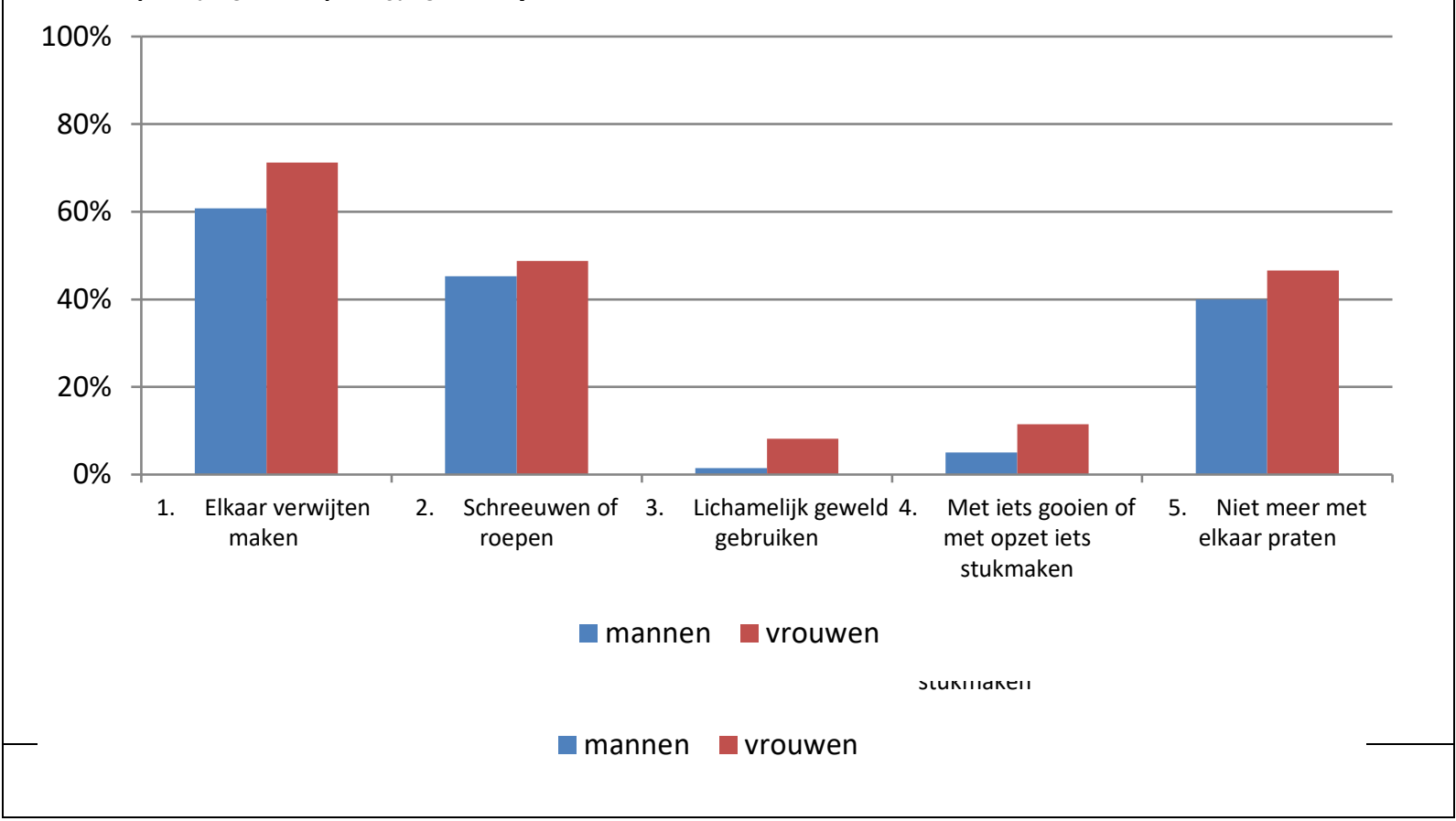

accumulation theory). Volgens Kalmijn en Monden (2006) kan een echtscheiding ook

gezien worden als een vlucht uit een negatieve situatie, op zoek naar verbetering. Dit impliceert dat gescheiden personen uit een huwelijk met veel conflict, zich eerder opgelucht zullen voelen na een scheiding en een beter psychisch welzijn zullen rapporteren (escape theory).

Theorieën over verlies en verwerking (Prigerson et al, 1999; DeGarmo \& Kitson, 1996) versterken deze idee en stellen dat gescheiden personen die vinden dat hun voorbije huwelijk kwalitatief goed was, doorgaans een lager welzijn rapporteren aangezien zij wellicht meer verloren dan gewonnen hebben bij de scheiding (een kwaliteitsvolle langetermijnrelatie). Onderzoek naar de blijvende impact van conflict is dus niet eenduidig. Bovendien is dergelijk onderzoek dikwijls niet toegespitst op conflict bij echtscheiding, worden andere indicatoren van welzijn dan depressiviteit vaak genegeerd, of hebben ze geen oog voor mogelijke geslachtsverschillen.

In vergelijking met de maat voor conflict in de huidige relatie met de ex-partner, scoren mannen en vrouwen duidelijk hoger op de maat die peilt naar conflict tijdens het voorbije huwelijk (Tabel 1). Dit verschil geeft aan dat met de echtscheiding vetes tussen ex-partners doorgaans drastisch afzwakken. Indien ex-partners vaak met elkaar in conflict waren tijdens het laatste jaar van het huwelijk (minimaal enkele keren per maand), ging het quasi steeds om verwijten maken, schreeuwen of roepen, of niet meer praten met elkaar (Figuur 6). Lichamelijk geweld komt maar in een klein aantal 
van de gevallen voor, maar wordt toch door $8 \%$ van de gescheiden vrouwen gerapporteerd. Doorgaans schrijven vrouwen gemiddeld meer conflict toe aan het voorbije huwelijk dan mannen $(R=0,255, p<0.01)$.

\subsection{MANNEN, VROUWEN EN CONFLICT}

De impact van conflict op welbevinden verschilt tussen mannen en vrouwen. Volgens genderroltheorieën wordt het welzijn van mannen vooral bepaald door de mate waarin zij macht, autonomie en controle ervaren, en persoonlijk succes behalen, en dat van vrouwen door de aard van hun sociale relaties en hoe goed ze in staat zijn om deze te behouden (Bracke, 1998, 2000; Courtenay, 2000; Kalmijn and Monden, 2006; McBride et al., 2005). Meer dan mannen, zijn vrouwen het sociale bindmiddel van (vrienden)groepen en familie. Daarom verwachten we dat conflict meer impact heeft op het welzijn van vrouwen dan van mannen.

\section{DE RELATIE TUSSEN CONFLICT EN WELBEVINDEN NA ECHTSCHEIDING}

Samenvattend verwachten we (1) algemeen een negatieve invloed van conflict op alle indicatoren van mentale gezondheid, met uitzondering van conflict tijdens het voorbije huwelijk waarvoor zowel een positieve als negatieve relatie met welbevinden mogelijk is; en (2) dat de impact van conflict meer voelbaar is voor vrouwen dan voor mannen.

In lijn met eerder onderzoek tonen de data van Scheiding in Vlaanderen aan dat het aangaan van een nieuwe partnerrelatie positief gerelateerd is aan welzijn, ongeacht de familiale- of financiële situatie: zowel gescheiden mannen als vrouwen met een nieuwe partner rapporteren doorgaans minder depressieve gevoelens, meer levenstevredenheid, en hogere niveaus van zelfwaardering (Tabel 3 en Tabel 4). Vrouwen met een nieuwe partner scoren gemiddeld ook hoger op omgevingsbeheersing. Echter, conflict binnen deze nieuwe partnerrelatie zorgt voor een substantiële afname van dit positieve effect 
Tabel 3. De mentale gezondheid van gescheiden vrouwen en conflict met de nieuwe partner en expartner (Scheiding in Vlaanderen 2009-10; resultaten GLM ( $N=445)$ )

\begin{tabular}{|c|c|c|c|c|c|c|c|c|c|c|c|c|}
\hline & \multicolumn{3}{|c|}{$\begin{array}{c}\text { Depressiviteit } \\
\begin{array}{c}(0-24) \\
(\mathrm{N}=445)\end{array} \\
\end{array}$} & \multicolumn{3}{|c|}{$\begin{array}{c}\text { Zelfwaardering } \\
(0-40) \\
(\mathrm{N}=445) \\
\end{array}$} & \multicolumn{3}{|c|}{$\begin{array}{c}\text { Omgevingsbeheersing } \\
(0-28) \\
(\mathrm{N}=445) \\
\end{array}$} & \multicolumn{3}{|c|}{$\begin{array}{l}\text { Levenstevreden- } \\
\text { heid }(0-10) \\
(\mathrm{N}=445) \\
\end{array}$} \\
\hline & B & $\mathrm{SE}(\mathrm{B})$ & Sig. & $\mathrm{B}$ & $\mathrm{SE}(\mathrm{B})$ & Sig. & B & $\mathrm{SE}(\mathrm{B})$ & Sig. & $\mathrm{B}$ & $\mathrm{SE}(\mathrm{B})$ & Sig. \\
\hline Intercept & ,39 & 2,21 & & 31,11 & 3,05 & $* * *$ & 21,95 & 2,33 & $* * *$ & 9,60 & ,88 & $* * *$ \\
\hline Huwelijksconflict (beide) &,- 01 & ,04 & &,- 08 & ,06 & &,- 02 & ,05 & & ,03 & ,02 & $*$ \\
\hline Conflict met ex (beide) & ,24 & 12 & $*$ &,- 26 & ,16 & &,- 33 & 12 & $* *$ &,- 02 & 05 & \\
\hline Conflict met partner & ,44 & 11 & $* * *$ &,- 32 & ,15 & $*$ &,- 34 & 11 & $* *$ &,- 23 & ,04 & $* * *$ \\
\hline Partner (ja) & $-2,62$ &, 50 & $* * *$ & 1,24 & 68 & $(*)$ & 1,65 &, 52 & $* *$ & 1,47 & 20 & $* * *$ \\
\hline Contact ex-partner (ja) &,- 62 &, 52 & & 10 & ,72 & & ,31 & ,55 & &,- 16 & ,21 & \\
\hline
\end{tabular}

Noot: Alle analyses controleren voor leeftijd, de tijd sinds echtscheiding, het hebben van minderjarige kinderen met de ex-partner, hoogst behaalde opleidingsniveau, werkstatus en financiële situatie (relatief equivalent huishoudinkomen). Sterretjes geven het significantieniveau aan: ${ }^{* * *}(\mathrm{p}<=.001),{ }^{* *}(\mathrm{p}<=.01),{ }^{*}(\mathrm{p}<=.05),\left({ }^{*}\right)(.05<\mathrm{p}<=.08)$. Aangepaste $\mathrm{R}^{2}=, 159$ (depressie); ,057 (zelfwaardering); ,093 (omgevingsbeheersing); ,181(levenstevredenheid)

Tabel 4. De mentale gezondheid van gescheiden mannen en conflict met de nieuwe partner en expartner (Scheiding in Vlaanderen 2009-10; resultaten GLM ( $N=445)$ )

\begin{tabular}{|c|c|c|c|c|c|c|c|c|c|c|c|c|}
\hline & \multicolumn{3}{|c|}{$\begin{array}{c}\text { Depressiviteit } \\
(0-24) \\
\end{array}$} & \multicolumn{3}{|c|}{$\begin{array}{c}\text { Zelfwaardering } \\
(0-40)\end{array}$} & \multicolumn{3}{|c|}{$\begin{array}{c}\text { Omgevingsbeheersing } \\
(0-28)\end{array}$} & \multicolumn{3}{|c|}{$\begin{array}{c}\text { Levenstevredenheid } \\
(0-10)\end{array}$} \\
\hline & \multicolumn{3}{|c|}{$(\mathrm{N}=445)$} & \multicolumn{3}{|c|}{$(\mathrm{N}=445)$} & \multicolumn{3}{|c|}{$(\mathrm{N}=445)$} & \multicolumn{3}{|c|}{$(\mathrm{N}=445)$} \\
\hline & B & $\mathrm{SE}(\mathrm{B})$ & Sig. & B & $\mathrm{SE}(\mathrm{B})$ & Sig. & $\mathrm{B}$ & $\mathrm{SE}(\mathrm{B})$ & Sig. & B & $\mathrm{SE}(\mathrm{B})$ & Sig. \\
\hline Intercept & 3,28 & 1,86 & $(*)$ & 30,59 & 2,72 & $* * *$ & 19,94 & 2,28 & $* * *$ & 8,54 & ,89 & $* * *$ \\
\hline Huwelijksconflict (beide) &,- 04 & ,04 & &,- 02 & ,05 & & ,05 & ,04 & & ,02 & ,02 & \\
\hline Conflict met ex (beide) & ,25 & 10 & $* *$ &,- 11 & 14 & &,- 13 & 12 & &,- 02 & ,05 & \\
\hline Conflict met partner & ,42 & ,08 & $* * *$ &,- 08 & 12 & &,- 06 & 10 & &,- 16 & ,04 & $* * *$ \\
\hline Partner (ja) & $-2,67$ & 37 & $* * *$ & 1,43 &, 54 & $* *$ & ,71 & ,46 & & 1,65 & 18 & $* * *$ \\
\hline Contact ex-partner (ja) &,- 21 & ,41 & &,- 32 & ,59 & &,- 38 &, 50 & &,- 23 & 19 & \\
\hline
\end{tabular}

Noot: Alle analyses controleren voor leeftijd, de tijd sinds echtscheiding, het hebben van minderjarige kinderen met de ex-partner, hoogst behaalde opleidingsniveau, werkstatus en financiële situatie (relatief equivalent huishoudinkomen). Sterretjes geven het significantieniveau aan: ${ }^{* *}(\mathrm{p}<=.001),{ }^{* *}(\mathrm{p}<=.01),{ }^{*}(\mathrm{p}<=.05),\left({ }^{*}\right)(.05<\mathrm{p}<=.08)$. Aangepaste $\mathrm{R}^{2}=, 139$ (depressie); ,031 (zelfwaardering); ,018 (omgevingsbeheersing); ,209 (levenstevredenheid)

op depressieve gevoelens en levenstevredenheid voor mannen en vrouwen, alsook op 
zelfwaardering en omgevingsbeheersing voor vrouwen.

Toch halen mannen en vrouwen die veel conflict rapporteren in hun nieuwe relatie (+2 standaardafwijkingen boven het gemiddelde) doorgaans betere niveaus van mentale gezondheid dan zij die geen nieuwe partner hebben.

Wat betreft de huidige relatie met de ex-partner tonen Tabel 3 en Tabel 4 dat contact houden met de ex-partner niet inherent positief of negatief voor het welzijn is, maar dat conflictueuze relaties na echtscheiding wel degelijk schade berokkenen aan het welbevinden: meer conflict met de ex-partner is voor zowel mannen als vrouwen gerelateerd aan meer depressieve gevoelens, en voor vrouwen ook aan verminderde gevoelens van omgevingsbeheersing.

De mate waarin het voorbije huwelijk gekenmerkt werd door conflict is evenwel niet gerelateerd aan verminderd psychisch welzijn, voor vrouwen noch mannen. Meer conflict tijdens het laatste jaar van het huwelijk gaat voor vrouwen zelfs gepaard met licht verhoogde scores voor levenstevredenheid na echtscheiding (Tabel 3).

Ten slotte blijkt uit de controlevariabelen (voor een overzicht zie onderaan Tabel 3 en Tabel 4, resultaten niet weergegeven) dat de mentale gezondheid van vrouwen die geen kinderen hebben met hun ex-partner best is. Zij zijn meer tevreden en hebben een hogere omgevingsbeheersing. Voor mannen is dat niet zo.

\section{Conclusie}

Centraal in dit onderzoek staat de vraag of, en in welke mate, conflict in (ex-)partnerrelaties een impact heeft op het welbevinden van gescheiden mannen en vrouwen. Concreet werden conflict tijdens het voorbije huwelijk, huidig conflict met de ex-partner, en conflict met de eventuele nieuwe partner onder de loep genomen, en werd hun relatie met een brede waaier aan zowel positieve als negatieve indicatoren van welzijn bestudeerd. Enkele interessante bevindingen betreffende de samenhang tussen welbevinden en relatiekwaliteit/conflict, werden gevonden.

Ondanks de groei in echtscheidingscijfers en de toegenomen individualisering, zijn partnerrelaties nog steeds van centraal belang voor de identiteit van mannen en vrouwen: gescheiden personen die een nieuwe partner hebben, rapporteren gemiddeld minder gevoelens van depressiviteit en meer zelfwaardering, omgevingsbeheersing en levenstevredenheid dan zij die geen nieuwe partner hebben, zelfs indien deze relaties gekenmerkt worden door veel conflict. Dit doet uitschijnen dat mensen naar verbondenheid zoeken, tegen welke prijs ook.

In lijn met genderroltheorieën verwachtten we dat vooral vrouwen gevoelig zijn voor conflict. De resultaten tonen aan dat voor zowel mannen als vrouwen conflict in intieme relaties gepaard gaat met verhoogde gevoelens van depressiviteit en een mindere levenstevredenheid. Toch blijkt dat deze relatie meer uitgesproken is voor vrouwen. Zo zijn deze effecten niet alleen sterker voor vrouwen, maar gaat conflict met de nieuwe partner bij hen ook gepaard met verminderde gevoelens van zelfwaardering en omgevingsbeheersing. Relatiebemiddeling kan dus zinvol zijn voor beide partners, al is het mogelijk dat vrouwen er iets meer de vruchten van plukken. Wat conflict tussen ex-partners betreft, blijkt dat conflict doorgaans sterk afneemt na de echtscheiding in vergelijking met wat gerapporteerd werd betreffende het laatste jaar van het huwelijk. Desondanks is het wel zo dat indien er nog conflict is tussen ex-partners, dit gepaard gaat met verhoogde gevoelens van depressiviteit bij zowel mannen als vrouwen, en ook met verminderde gevoelens van omgevingsbeheersing bij vrouwen. 
Ten slotte merkten we ook op dat conflict geen blijvende impact lijkt te hebben. In tegenstelling tot conflict in huidige relaties, zijn conflictniveaus van het voorbije huwelijk niet significant gerelateerd aan een verlaagd welzijn. Integendeel, vrouwen wiens huwelijk door meer conflict gekenmerkt werd, zijn nu zelfs doorgaans meer tevreden met hun leven. Hoewel de grootte van het effect klein is, is het wel een indicatie in lijn met de vluchthypothese. Uit eerder onderzoek weten we ook dat het meestal de vrouw is die het initiatief neemt voor de echtscheiding (Baum, 2006). Omdat het psychosociaal aanpassingsproces van zij die de scheiding aanvragen reeds eerder begint, kan dit mee verklaren waarom vrouwen het doorgaans beter stellen dan mannen achteraf. Hieruit volgt ook dat echtscheidingsbemiddeling of -therapie een belangrijke rol kan spelen ter verbetering van het welzijn van mannen. Hun welzijn is immers voornamelijk afhankelijk van macht en de ervaring van controle en autonomie. Door mannen op hun beurt meer controle te helpen krijgen over het echtscheidingsproces en over relaties na de scheiding, kan dit hun welzijn ten goede komen.

\subsection{BELEIDSAANBEVELINGEN}

Dit onderzoek leert dat problemen en conflicten in partnerrelaties een groot effect hebben op het psychisch welbevinden van mannen en vrouwen. Eerst en vooral kan echtscheidingsbemiddeling een belangrijke rol spelen in het kanaliseren en temperen van conflict tussen ex-partners aangezien een onpartijdig persoon helpt de zaken optimaal te regelen (Lowenstein, 2009; Vander Steene, 2007). Sinds 2001 wordt echtscheidingsbemiddeling als mogelijke eerste lijn naar voren geschoven in het echtscheidingsproces, en sinds de wetswijziging van 2006 wordt de rechter ook verplicht koppels te informeren over het bestaan en de mogelijkheid tot bemiddeling in familiezaken. Evenwel loopt dit nog niet vlot. Zo wordt bemiddeling pas voorgesteld eens beide partners in de rechtbank verschijnen, een moment wanneer de grootste conflicten reeds gestart zijn en bijgevolg elke bemiddelingspoging veel minder kans op slagen heeft. Voorts blijkt dat deze meldingsplicht inzake het bestaan van echtscheidingsbemiddeling in een groot deel van de gevallen niet nagekomen wordt (Bastaits, Van Peer, Alofs, Pasteels \& Mortelmans, 2011). Rechters wijzen op hun meldingsplicht en hen overtuigen van het belang van bemiddeling kan een belangrijke eerste stap zijn.

Hoewel vanuit de overheid veel ingezet wordt op echtscheidingsbemiddeling, toont dit en ander onderzoek aan dat tevens meer middelen vrijgemaakt moeten worden voor relatie- en gezinstherapie, en voor nazorgbemiddeling. Therapie kan helpen conflicten te beheersen en te kanaliseren, en zo relaties, ook na de echtscheiding, te optimaliseren. Door het toenemend aantal co-ouderschapregelingen zijn steeds meer ex-partners 'gedwongen' contact met elkaar te houden en tot gezamenlijke beslissingen te komen. Het optimaliseren van hun welzijn, het vermijden van "tweede" echtscheidingen, en zo ook het drukken van juridischeen gezondheidskosten voor de hele samenleving, moet een belangrijk aandachtspunt zijn. Uit eerder onderzoek weten we dat nieuwe partnerrelaties na echtscheiding bovendien een verhoogd risico dragen om te mislukken. Het stimuleren en toegankelijker maken van relatie- en gezinstherapie en/of conflictbemiddeling ook voor deze nieuwe relaties, kan helpen de negatieve spiraal te stoppen. Onderzoek naar de impact van relatiebemiddeling toont immers aan dat het gebruik maken van bemiddeling leidt tot een beter welbevinden van alle partijen, inclusief de kinderen (Walton, Olliver \& Griffin, 1999).

\subsection{BEPERKINGEN VAN HET ONDERZOEK}

Opdat de resultaten correct geïnterpreteerd worden, moeten we vermelden dat deze studie 
beperkt is in enkele opzichten. Ten eerste werden enkel die personen opgenomen die maximaal één keer en maximaal 10 jaar geleden gescheiden zijn. Aangezien vandaag ongeveer één op tien echtscheidingen een scheiding is waarbij minstens één van beide partners reeds een eerdere echtscheiding achter de rug heeft, reflecteert deze steekproef de groep van de gescheiden personen niet helemaal. Bovendien werden enkel zij opgenomen wiens ex-partner ook deelnam aan de studie.

Ten tweede beschikken we niet over longitudinale data, d.w.z. over verschillende metingen doorheen de tijd (bv van mentale gezondheid), waardoor we voorzichtig moeten zijn met het leggen van causale verbanden. Het is immers mogelijk dat de relatie tussen conflict en mentale gezondheid deels ook in de omgekeerde richting verklaard kan worden: dat diegenen die zich minder goed voelen mogelijks sneller geneigd zijn problemen en conflicten te rapporteren.

Ten derde werd de maat van conflict tijdens het laatste jaar van het voorbije huwelijk gemeten aan de hand van retrospectieve bevraging. Het is mogelijk dat antwoorden hierop vertekend werden door o.a. de huidige relatiekwaliteit met de ex-partner, de tijd die verlopen is sinds de scheiding, of zelfs door het huidige psychisch welzijn van de respondent. Om deze reden werd een meer objectieve maat geconstrueerd door ook de inschatting van het conflict door de ex-partner in rekening te brengen (zie bijlage 2). Op dezelfde wijze werd een meer objectieve maat voor het huidige conflict met de ex-partner ontworpen. Het feit dat beide expartners onafhankelijk van elkaar bevraagd werden, biedt op deze manier wel een unieke meerwaarde.

\section{REFERENTIES}

Ahrons, C. R. (2007). Introduction to the special issue on divorce and its aftermath. Family Process, 46(1), 3-6.

Amato, P. R. (2000). The consequences of divorce for adults and children. Journal of Marriage and the Family, 62, 1269-1287.

Amato, P. R., \& Hohmann-Marriott B. (2007). A comparison of high- and low-distress marriages that end in divorce. Journal of Marriage and Family, 69, 621-638.

Bastaits, K. Van Peer, C. Alofs, E. Pasteels, I. \& Mortelmans, D. (2011). Hoe verloopt een echtscheiding in Vlaanderen? In: D. Mortelmans, I. Pasteels, P. Bracke, K. Matthijs, J. Van Bavel \& C. Van Peer (Eds.) Scheiding in Vlaanderen (pp. 85-111), Leuven: Acco.

Baum, N. (2006). Separation guilt in women who initiate divorce. Clinical Social Work Journal, 35(1), $47-55$.

Bracke, P. (1998). Depressiviteit en de economische gevolgen van echtscheiding voor vrouwen en mannen [Depression and the economic consequences of divorce for women and men]. Mens en Maatschappij, 73(3), 239-258.

Bracke, P. (2000). Over macht en depressiviteit: Een social-relationele visie [On power and depression: A social-relational perspective]. Tijdschrift voor Sociologie, 21(1), 5-30.

Booth, A., \& Amato P. R. (1991). Divorce and psychological stress. Journal of Health and Social Behavior, 32, 396-407.

Bradburn, N. M. (1969). The structure of Psychological Wellbeing. Chicago. IL: Aldine.

Cantril, H. (1965). The pattern of human concern. New Brunswick NJ: Rutgers University Press.

Courtenay, W. H. (2000). Constructions of masculinity and their influence on men's well- 
being: a theory of gender and health. Social Science and Medicine, 50, 1385-1401.

DeGarmo, D. S. \& Kitson, G. C. (1996). Identity relevance and disruption as predictors of psychological distress for widowed and divorced women. Journal of Marriage and the Family, 59(4), 983-997.

Evers, D. (2011). Feedbackgesprek in het kader van deze paper op 23/12/2011. Diana Evers is familiaal bemiddelaar, hoofd van Harabemiddeling (www.harabemiddeling.be) en mede oprichtster van De Scheidingsschool (www.descheidingsschool.be).

Fokkema, T. (2001). Forse inkomensdaling voor vrouwen na echtscheiding en vroege verweduwing: bieden hertrouw en werk uitkomst? [Remarkable decline in income for women after divorce and early widowhood.]. Bevolking en Gezin, 30, 5-29.

Horwitz, A. V.; McLaughlin, J., \& White, H. R. (1997). How the negative and positive aspects of partner relationships affect the mental health of young married people. Journal of Health and Social Behavior, 39, 124-136.

Kalmijn, M., \& Monden C. (2006). Are there negative effects of divorce on well-being dependent on marital quality? Journal of Marriage and the Family, 68, 1197-1213.

Lansford, J. E. (2009). Parental Divorce and Children's Adjustment. Perspectives on Psychological Science, 4(2), 140-152.

Lowenstein, L. F. (2009). Mediation with Separated Parents: Recent Research 2002-2007. Journal of Divorce and Remarriage, 50(4), 233-247.

Martens, I. (2007). Het verblijfsco-ouderschap als prioritair te onderzoeken verblijfsregeling. In P. Seynave, F. Swennen \& G. Verschelden (Eds.), Verblijfsco-ouderschap. Uitvoering en sanctionering van verblijfs- en omgangsregelingen. Adoptie door personen van hetzelfde geslacht (pp. 3-38). Antwerpen - Oxford: Intersentia.

Masheter, C. (1997). Healthy and unhealthy friendship and hostility between exspouses. Journal of Marriage and the Family, 59(2), 463-475.

McBride, C., Bacchiochi, J.R. \& Bagby, R.M. (2005). Gender differences in the manifestation of sociotropy and autonomy personality traits. Personality and Individual Differences, 38, 129-136.

Mirowsky, J. \& Ross, C. E. (1989). Psychiatricdiagnosis as reified measurement. Journal of Health and Social Behavior, 30(1), 11-25.

Mortelmans, D., Pasteels, I., Van Bavel, J., Bracke, P., Matthijs, K. \& Van Peer, C. (2011). Scheiding in Vlaanderen. Data collectie en code book. (http://www.scheidinginvlaanderen.be).

Nolen-Hoeksema, S., Larson, J. \& Grayson, C. (1999). Explaining the gender difference in depressive symptoms. Journal of personality and social psychology, 77(5), 1061-72.

Payton, A. R. (2009). Mental health, mental illness, and psychological distress: Same continuum or distinct phenomena? Journal of Health and Social Behavior, 50, 213-227.

Pearlin, L.I., Menaghan, E.G., Lieberman, M.A. \& Mullan, J.T. (1981). The stress process. Journal of Health and Social Behavior, 22(4), 337-356.

Prigerson, H. G., Maciejewski, P. K. \& Rosenheck, R. A. (1999). The Effects of Marital Dissolution and Marital Quality on Health and Health Service Use among Women. Medical Care, 37(9), 858-873.

Radloff, L. S. (1977). The CES-D Scale: A self-report depression scale for research in the general population. Applied Psychological Measurement, 1, 385-401. 
Rosenberg, M. (1965). Society and the adolescent self-image. Princeton: Princeton University Press.

Ross, C. E. (1991). Marriage and the sense of control. Journal of Marriage and the Family, 53(4), 831-838.

Ross, C.E. \& Mirowsky, J. (2002). Age and the gender gap in the sense of personal control. Social Psychology Quarterly, 65(2), 125-145.

Seff, M.A., Gecas, V. \& Ray, M.P. (1992). Injury and depression: The mediating effects of self-concept. Sociological Perspectives, 35(4), 573-591.

Shapiro, A. (1996). Explaining psychological distress in a sample of remarried and divorced persons. Journal of Family Issues, 17, 186203.

Simon, R.L. \& Marcussen, K. (1999). Marital transitions, marital beliefs and mental health. Journal of Health and Social Behavior, 40, 111-125.

Skaff, M.M., Pearlin, L.I. \& Mullan, J.T. (1996). Transitions in caregiving career: Effects on sense of mastery. Psychology and Aging, 11(2), 247-257.

Symoens, S., Colman, E., Pasteels, I. \& Bracke, P. (2011). Welbevinden van (ex-)partners en kinderen. In D. Mortelmans, I. Pasteels, P. Bracke, K. Matthijs, J. Van Bavel \& C. Van Peer (Eds.), (pp. 237-265). Leuven: Acco.

Terhell, E.L., Groenou, M.I. \& Van Tilburg T. (2007). Network contact changes in early and later postseparation years. Social Networks, 29(1), 11-24.

Thoits, P. A. (1994). Stressors and Problemsolving - The individual as psychological activist. Journal of Health and Social Behavior, 35(2), 143-160.

Umberson, D., Williams, K., Powers, D. A., Liu, H. \& Needham, B. (2006). You make me sick: Marital quality and health over the life course. Journal of Health and Social Behavior, 47(1), 1-16.

Vander Steene, A. (2007). Vroegtijdige eerstelijnshulpverlening in scheidingssituatie voorkomt vechtscheidingen. Tijdschrift voor Welzijnswerk, 31(283), 81-91.

Walton, L., Olliver, C. \& Griffin, C. (1999). Divorce mediation: The impact of mediation on the psychological wellbeig of children and parents. Journal of Community and Applied Social Psychology, 9(1), 35-46.

\section{WeBSITES}

\section{eurofound.europa.eu}

www.justitie.belgium.be

www.zorg-en-gezondheid.be

www.scheidinginvlaanderen.be 


\section{Appendix 1: Selectie respondenten}

Voor dit onderzoek beperkten we ons tot respondenten tussen 25 en 60 jaar die maximaal 10 jaar voorafgaand aan het interview in het kader van deze studie gescheiden zijn. Zij die nog eerder uit elkaar gingen, werden niet opgenomen aangezien zij meer risico lopen op retrospectieve vertekening voor een aantal centrale vragen. Mannen en vrouwen die minder dan één jaar voorafgaand aan het interview uit elkaar gingen, werden ook niet opgenomen aangezien hun antwoorden op de vraag naar conflict met de ex-partner de voorbije 12 maand deels overlapt met de indicator voor conflict tijdens (de laatste 12 maand van) het huwelijk (zie infra). Verder werden enkel zij wiens ex-partner ook deelgenomen had aan de studie opgenomen, in functie van een gecombineerde, meer objectieve maat voor conflict met de ex-partner (zowel voor conflict tijdens het huwelijk als nu; zie infra). Deze finale steekproef omvat 908 respondenten (454 mannen en 454 vrouwen). Van deze sample hebben 19 vrouwen en 16 mannen die een nieuwe partner hebben evenwel een ( $a d$ random) ontbrekende waarde op de maat voor conflict met de nieuwe partner. We kozen ervoor deze missings te vervangen door het gemiddelde. Op deze wijze worden effecten van deze conflictmaat niet vertekend en werd de steekproef ook niet verder ingeperkt. Daarnaast waren er ontbrekende waarden voor 3 vrouwen op de maat voor conflict in het voorbije huwelijk, en voor 3 mannen en 3 vrouwen op de maat voor conflict in de huidige relatie met de ex-partner. Aangezien voor deze variabelen de scores van beide partners noodzakelijk teneinde de gecombineerde maat te creëren, werden deze koppels uit de steekproef gelaten. De GLM analyses werden hierdoor op een finale steekproef van 445 mannen en 445 vrouwen uitgevoerd. 


\section{Appendix 2: Operationalisatie variabelen}

\section{A2.1. Mentale gezondheid}

Gevoelens van depressiviteit werden gemeten aan de hand van de 8-item versie van de CES-D schaal (Center for Epidemiologic Studies-Depression Scale) (Radloff, 1977). De CES-D is oorspronkelijk geconstrueerd om risicopopulaties voor het ontwikkelen van depressieve stoornissen te detecteren en mag bijgevolg niet gebruikt worden als klinisch tool op zich (Radloff, 1977). Respondenten werden gevraagd aan te duiden hoe vaak zij bepaalde zaken gevoeld of meegemaakt hebben in de week voorafgaand aan het interview (zich gedeprimeerd voelen, vinden dat alles wat men deed met moeite ging, slecht geslapen hebben, zich eenzaam voelen, van het leven genoten hebben, etc.). Antwoordcategorieën gaan van nooit of bijna nooit (0) tot altijd of bijna altijd (3). Scores voor de CES-D8 werden opgeteld, waarbij hogere scores staan voor een grotere frequentie en ernst van depressieve klachten (schaal 024). Betrouwbaarheid en validiteit van de schaal werd bevestigd voor geslacht en overheen landen (Van de Velde et al., 2010) (Cronbach's alpha $=0.86$.)

Zelfwaardering werd gemeten aan de hand van de Rosenberg self-esteem scale (Rosenberg, 1965). Deze bestaat uit 10 items waarop respondenten dienen aan te geven in welke mate ze al dan niet akkoord zijn. Voorbeelden zijn: "Ik ben in staat de meeste dingen even goed te doen als de meeste andere mensen", "Ik neem een positieve houding aan tegenover mezelf", en "Al bij al ben ik geneigd mezelf een mislukkeling te voelen". Antwoorden variëren van 1 (helemaal niet akkoord) tot 5 (helemaal akkoord). Voor 5 items werden de scores omgekeerd, zodat een hogere score steeds een hogere mate van zelfwaardering betekent (schaal 0-40). De schaal toont een goede betrouwbaarheid (Cronbach's alpha $=0.87$ ).

Omgevingsbeheersing werd gemeten aan de hand van Pearlin's 7-item mastery-schaal (Pearlin et al., 1981), waarvoor respondenten gevraagd worden of ze akkoord of niet akkoord gaan met zeven stellingen zoals: "Er is weinig dat ik kan doen om belangrijke dingen in mijn leven te veranderen", "Soms voel ik dat ik een speelbal van het leven ben", en "Ik kan ongeveer alles als ik m'n zinnen erop gezet heb". Antwoorden variëren van 1 (helemaal niet akkoord) tot 5 (helemaal akkoord). Voor vijf items werden de scores omgekeerd zodat een hogere scores steeds meer omgevingsbeheersing betekent (schaal 0-28). De schaal vertoont een goede betrouwbaarheid (Cronbach's alpha $=0.81$ ).

Levenstevredenheid tenslotte werd gemeten aan de hand van de vraag "Hoe tevreden of ontevreden bent u met uw leven tegenwoordig?", dewelke komt uit de European Social Survey (2006). Antwoorden variëren van 0 (helemaal niet tevreden) tot 10 (helemaal tevreden).

\section{A2.2. Conflict}

Voor alle drie de maten van conflict (eerder huwelijksconflict; huidig conflict met de ex-partner; huidig conflict met de nieuwe partner) werd een gelijkaardige maat gebruikt. Deze maat werd onttrokken uit de vraag 'Hoe vaak deden de volgende situaties zich voor (a) tussen u en uw ex-partner in het jaar voor $u$ definitief apart ging wonen?, of (b) tussen u en uw ex-partner, resp. uw nieuwe partner gedurende de voorbije 12 maanden?: 'Elkaar verwijten maken'; 'schreeuwen of roepen'; 'fysiek geweld 
gebruiken'; 'zaken met opzet stukmaken'; en 'niet meer met elkaar praten voor een tijd'. Antwoordscores variëren van 1 (= nooit) tot 7 (= dagelijks). Samengeteld is dit een maat van $5-35$, omgezet van $0-30$.

Voor het voorbije huwelijksconflict en het huidig conflict met de ex-partner werden gemiddelden berekend gebaseerd op de scores van beide ex-partners ( $R_{\mathrm{P} 1-2}$ huwelijks conflict $=0,255^{* *} ; R_{\mathrm{P} 1-2}$ huidig conflict $\left.=0,310^{* *}\right)$. Op deze wijze bieden we een meer objectieve maat die minder onderhevig is aan het welzijn van de respondent en/of retrospectieve vertekening. Scores variëren van 0 tot 30 . De indicator voor huidig conflict met de ex-partner controleert voor het al/niet nog hebben van contact met elkaar. Evenzo controleert de maat voor conflict met de nieuwe partner of de respondent samenleeft met een nieuwe partner of niet. Zij die geen nieuwe partner hebben scoren 0 .

\section{A2.3. Controlevariabelen}

Ter controle werden opgenomen: leeftijd (continu), het al dan niet hebben van minderjarige kinderen met de ex-partner, hoogst behaalde opleidingsniveau ( 3 categorieën: lager secundair onderwijs of minder (cat1); hoger secundair of postsecundair, niet hoger onderwijs (cat2); hoger niet academisch of academisch onderwijs (cat3, ref.cat)), en huishoudinkomen (gemeten volgens de 'Equivalent Income OECD modified scale' (Haagenars et al, 1994), bestaande uit 5 categorieën: zij met minder dan 50\% van het gemiddeld equivalent huishoudinkomen (cat1); zij van $50 \%$ tot $79 \%$ (cat2); zij van $80 \%$ tot $119 \%$ (cat3, ref.cat); zij met $120 \%$ of meer van het gemiddeld equivalent huishoudinkomen (cat4); en een aparte categorie voor wie geen info verschafte over het huishoudinkomen (cat5). Tenslotte wordt ook de tijd sinds de scheiding opgenomen. Dit zijn het aantal jaren verstreken sinds beide partners apart gingen wonen. Twee categorieën werden aangemaakt: één voor zij die minder dan 3 jaar geleden gescheiden zijn (d.i. wonen in aparte huishoudens), en één voor zij die meer dan 3 jaar geleden uit elkaar gingen (=ref.cat). Drie jaar wordt als cut-off genomen aangezien sommige onderzoeken aantonen dat na 2 à 3 jaar het welzijn van gescheiden mannen en vrouwen weer haar oorspronkelijke niveau bereikt. 


\section{ENGLISH ABSTRACT}

Changes in social relations can have a substantial impact on the wellbeing of ex-partners after divorce. This research focusses on conflict in initimate relationships with both a new partner as with the exspouse, and its relationship with a broad array of indicators of both negative and positive mental health. The data of the project "Divorce in Flanders" is used. Analyses are conducted on a subsample of 908 divorced men and women.

Compared to the last year of marriage, only little conflict is reported in current relations between exspouses. If there is conflict, this is associated with lower wellbeing, though more pronounced for women. The same holds for conflict with the new partner. Remarkable is that partnerrelationships are still of central importance for the identity of men and women: those who have a new partner are in general more satisfied and less unhappy, even if this relationship is characterised by conflict. Finally, divorced women, but not men, whose prior marriage was characterised by high conflict, are in general more satisfied with their lives. 